To combat this situation, a systematic and massive programme of refresher courses-is required. Such a programme could be provided in the long vacations at selected universities and technical colleges and, because of its close liaison with these academic institutions and with industry, the Institute would be well placed to administer it for chemists.

Finally, the Institute proposes to devote a proportion of its funds to assisting the teaching of chemistry in the developing countries, especially the newly independent countries of the British Commonwealth. Help that might be given includes the provision of symposia and refresher courses for teachers, the secondment of teachers from the
United Kingdom, and the provision of all kinds of visual aids and of programmed learning techniques.

By acting as a pioneer and 'pump-primer' in the ways suggested in this article, the Institute feels that it can best exercise its function as an independent professional body in promoting the development of chemical education and ensuring an adequate supply of properly trained chemists to meet national needs in the United Kingdom and in the developing countries of the Commonwealth.

Further details about the proposals are contained in an appeal booklet available from the Royal Institute of Chemistry, 30 Russell Square, London, W.C.1.

\title{
OBITUARIES
}

\section{Sir Ronald Hatton, C.B.E., F.R.S.}

Sir Ronald Hatton died on November 11, 1965, in his eightieth year at his home in Benenden, Kent.

On leaving Balliol College, Oxford, he went to the South Eastern Agricultural College, Wye, Kent, and soon afterwards became a member of the horticultural staff there. Later he was transferred to the newly established Wye College Expərimental Station at East Malling, whore he assisted Wellington, the first director. After the First World War, Hatton was appointed director and remained so until his retirement in 1949. Under his guidance, despite numerous financial difficulties, the Station rapidly developed and attained a world-wide reputation. During the formative period he was whole-heartedly supported by the fruit industry of the United Kingdom and a devoted staff. When he retired he had the satisfaction of knowing that horticultural science was fully recognized as an essential service to the fruit-growing industry.

Hatton's own research in the 'twenties on rootstocks was a major turning-point in fruit culture. There were then wide variations within the same orchard in tree size and fruit quality: Hatton aimed at obtaining uniformity in both, and his research resulted in a series of rootstocks which imparted to the scion standardized growth charecteristics. This was a major, if not the major, development for fruit culture throughout the world. Order was created out of chaos, for his work made possible a planned pattern for orchards and prepared the way for future trends in orchard practice, including, in particular, extensive mechanization. As a result, orehards of the future will be planted for high yiolds at the lowest possible costs.

Although pomological research remained his great interest, Hatton was fully alive to the importance of developing at the Research Station ancillary subjects such as plant physiology, applied entomology, plant pathology and statisties.

His delightful and friendly personality inspired confidence and was a constant stimulus to everyone, both in the Station and outside. His staff were known as "Hatton's boys" and there was among them a wonderful productive team spirit. His appetite for work was enormous and he was never satisfied that enough progress had been made. Perhaps his only fault-a forgivable onewas that he failed to realize anyone grew older, and although he knew that progress must require additional staff, he dreaded the Station expanding beyond a scientific "family circle".

Among his many achievements was the major part he took in the establishment of the Imperial Bureau of Fruit Production at East Malling, of which he was consultant director. His interests went far beyond his own Station: he was generous-minded to all and he had innumereble fruit-grower friends, who took his advice because it was so forward-thinking and practical. Undoubtedly there was in him a most happy blending of science and horticultural technology, which plays such a big part in the well-being of a erop research station. The fruit-growing industry will for over owe a great debt of gratitude to Sir Ronald Hatton.

H. G. H. Kearns

\section{Prof. E. J. Dijksterhuis}

IN 1924, Eduard Jan Dijksterhuis, an obscure mathematics teacher in the Tilburg secondary school, published a book, Val en Worp, sub-titled "Contribution to the History of Mechanics from Archimedes to Newton", which was actually a summary of all that history could tell on this subject at that time, written by somebody who was obviously a master in this art.

Although the history of mathematics had flourished in The Netherlands for many years around the monumental work of editing Christian Huygons's works and the discovery and publishing of Isaac Bcekman's journal, Dijksterhuis as a historian was an autodidact. $\mathrm{He}$ had attended the secondary school in Tilburg, where his fathor was the principal. Then, in order to be admitted to a university, he prepared for the final examination of a grammar school; this he passed after one year, at the age of seventeen. Still considered by his parents to be too young to study at a university, he spent one more year at home, during which he immersed himself in the classies, with which he had fallen in love during the preparations for his examination. Nevertheless, at the University of Groningen he chose his older favourite, mathematics, as his major subject. In 1918 he gained a doctor's degree for a thesis on a geometrical subject. Meanwhile, he had already taught at a Groningen girls' school, but in 1919 he agreed to fill a vacancy at the Tilburg school where he had been a student. This commitment did not end until 1953, when he was appointed a professor extraordinary in the history of mathematies and exact sciences at the University of Utrecht; from 1954 he also held an equivalent post at the University of Leiden. From 1960 until his retirement in 1963 he was a professor ordinary at the University of Utrecht.

From his marriage in 1920 with Johanna K. E. Niemeyer until his departure to Utrecht in 1953 he lived in the lovely Brabant town of Oisterwijk. In this rustic climate he matured as a scholar, and he wrote the greater part of his work. But he did not lead a retired life. For many years he was a 'privaat-docent' at the Universities of Amsterdam and Leiden-an activity which was interrupted by the Second World War. Ho played a great part in commissions on the teaching of mathematics and mechanics, and from 1934 until 1958 was a member of the Government Education Council (Onderwijsraad). For nearly a quarter of a century he was an honorary secretary to the most outstanding Netherlands literary periodical, De Gids. But, first of all, he was admired as a lecturer because of his firm grasp of the subject and the easy command of the language in which he expressed his thoughts. 
His Val en Worp was followed in 1929-30 by his commentary (in Dutch) on Euclid's Elements. His Archimedes was written before the War; its English translation appeared in 1956. In 1943 his Simon Stevin appeared, and in 1950 the best known of his works, De Mechanisering van het Wereldbeeld, was published; the latter has been translated into German and English. Besides these books, he published a large number of papers, lectures and addresses on historical, educational and philosophical subjects. His longest-lasting activity was that of chairman of the Royal Netherlands Academy Commission on the Edition of Works of Simon Stevin, which still met at his home when he had lost his speech and had to rely on gestures to conduct its meetings.

Educated people, and above all scholars of the humanities, were struck by his style. $\mathrm{He}$ abstained completely from metaphors, puns, oratorical and dramatic effects, and from any choice of words that would excite emotions rather than thoughts. He was a lover of art and poetry, but in his own work he never gave way to the spell of rhetorie. He put his thoughts into a form which matched their contents, and above all matched his character. $\mathrm{He}$ wished to grip the reader by the subject rather than by the form - though just for this reason it was the form which fascinated.

For his De Mechanisering van het Wereldbeeld he was awarded a high literary honour; he was a member of the Royal Notherlands Academy of Sciences, a bearer of the Karl Sudhoff Medal of the Deutsche Gesellschaft für Geschichte der Medizin, Naturwissenschaften und Technik, the George Sarton Medal of the American History of Science Society and many other honorary awards.

\section{H. Freudenthal}

\section{Prof. R. H. Hopkins}

Prof. R. H. Hopkrns, who was formerly Adrian Brown professor of brewing and applied biochemistry in the University of Birmingham, died recently after a short illness at his home in Bournemouth, aged seventy-four.

His association with Birmingham was a long one, as he graduated in 1910, after which he gained experience in various analytical laboratories. He returned to the University towards the end of the First World War and became assistant to the first professor of brewing, Prof. Adrian Brown.

He became a Fellow of the Royal Institute of Chemistry in 1918, and served on the Council for two periods.

In 1920 he took up an appointment in the Department of Chemistry of the Heriot-Watt College, Edinburgh, and was in charge of courses in melting and brewing and biochemistry. In 1926 he was awarded an M.Sc., and in 1928 a D.Sc. of Birmingham. When the Adrian Brown chair of malting and brewing fell vacant in Birmingham, his record and qualifications rendered him a very appropriate candidate, and he wus appointed in 1931.

Hopkins always, and rightly, insisted that the bioehemical principles on which the art of malting and brewing rested were of fundamental importance, and he strongly resisted attempts to isolate the School of Brewing. He was able to maintain the dual nature of the Department as a School of Brewing and Department of Industrial Fermentation, later of Applied Biochemistry. There is little doubt that without this steady pressure over the years there would have been no Department of Biochemistry as it exists to-day.

He was primarily a man of academic interests, but he combined this to a very unusual degree with a knowledge and appreciation of the technical processes and problems involved in malting and brewing. 'This is clearly demonstrested in the large number of papers which he contributed to the Journal of the Institute of Brewing, the Biochemical Journal and other journals of a more technical nature. There is scarcely any fundamental aspect of malting and brewing which he failed to deal with in his publications.

A topic which held his sustained interest over a number of years was the nature of starch and the complex amylolytic actions involved in its breakdown. He did much to bring order and clarity into a field of research where confusion reigned, and his claim to recognition will doubtless be confirmed in future perspective.

He directed a team of research workers in the Department under the aegis of the Institute of Brewing from 1934 until 1950, when it became absorbed in the Brewing Industry Research Foundation in Surrey. During the Second World War he sponsored work by the teaching staff on the qualitative and quantitative aspects of vitamins in beer. Most of the water-soluble vitamins came under scrutiny, and the large and useful amounts of riboflavin which occurred naturally in the beverage were reported for the first time.

$\mathrm{He}$ was a frequent participator in symposia and congresses throughout the Western world, and made several lecture tours of the United States.

His other interests included a deep appreciation of many branches of music, and he was particularly fond of holidays in the mountains and by the lakes of the Con. tinent. He will be missed by a host of colleagues, students and friends.
F. W. NORRIS

\section{NEWS and VIEWS}

\section{European-American Committee on Reactor Physics}

DR. V. RaIevski, head of the Reactor Physics Depart. ment at the Ispra Joint Nuclear Research Centre of Euratom, hes been elected chairman of the EuropeanAmerican Committee on Reactor Physics for the next 2 years. Dr. Raievski succeeds Mr. Peter Mummery of the Atomic Energy Establishment, Winfrith, U.K. At the same time, Dr. H. Kouts, of Brookhaven National Laboratory, has been elected scientific secretary of the Committee in succession to $\mathrm{Mr}$. F. Critoph of Atomic Fnergy of Canada, Ltd., Chalk River. The EuropeanAmerican Committee on Reactor Physics is a group of fifteen reactor physics experts from member countries of the Organization for Eeonomic Co-operation and Development, and Euratom (nine from Western Europe, three from the United States, one each from Canada, Japan and Euratom). It was set up in 1962 by the Steering Committee of the European Nuclear Energy Agency, which recently confirmed its mandate for a further 4-yeas period. The work of the Committec consists of reviews of national programmes in reactor physies, periodical examination of research on selected topics, and exchange of information on new research results. The Committee also advises on priorities for new research activities.

\section{Analytical Chemistry in the National Bureau of Standards: Dr. David H. Freeman}

Dr. David H. Freeman recently joined the Analytical Chemistry Division of the Institute for Materials Research at the National Bureau of Standards. His work will be concerned with the prediction, control and reproducibility of analytical separations, and he will deal especially with the relationships between chemical specificity and the structure of ion-exchange derivatives of synthetic orgenic copolymers. Dr. Freeman was formerly an assistant. professor at Washington State University, where his 